\title{
ANALISIS KESUKSESAN PENERAPAN SISTEM INFORMASI PREDIKSI CUACA WEATHER RESEARCH AND FORECASTING DALAM MENDUKUNG PROYEK TEKNOLOGI MODIFIKASI CUACA
}

\author{
Hendra Arisman, Budi Hartono \\ Universitas Gadjah Mada (UGM) Yogyakarta, Indonesia \\ Email: hndrarisman@gmail.com, boed@ugm.ac.id
}

\begin{abstract}
Abstrak
Setiap proyek yang dijalankan selalu didukung dengan sarana dan prasarana yang memadai guna mencapai tujuan akhir dari proyek tersebut. Proyek teknologi modifikasi cuaca (TMC) merupakan sebuah proyek yang unik dimana proyek ini bertujuan untuk meningkatkan intensitas curah hujan ataupun mempercepat proses hujan di suatu tempat. Sistem informasi Weather Research and Forecasting (WRF) merupakan salah satu sarana yang digunakan guna mendukung proyek TMC dengan menyediakan data informasi prediksi cuaca yang dibutuhkan. Mengingat pentingnya peran sistem WRF dalam proyek TMC ini sehingga dirasa perlu dilakukan evaluasi guna mengetahui keberhasilan implementasi dari sistem WRF tersebut. Penelitian ini melakukan evaluasi implementasi sistem informasi WRF diukur dari tingkat kepuasan dan net benefit yang dirasakan pengguna sistem di lingkungan unit kerja Balai Besar Teknnologi Modifikasi Cuaca pada intansi Badan Pengkajian dan Penerapan Teknologi (BPPT). Penelitian ini menggunakan Model Kesuksesan Sistem Informasi DeLone dan McLean yang dimodifikasi dengan menghilangkan konstruk penggunaan (use). Penelitian ini digunakan untuk menguji apakah kualitas sistem (system quality), kualitas informasi (information quality), dan kualitas pelayanan (service quality) berpengaruh positif terhadap kepuasan pengguna sistem (user satisfaction), serta menguji apakah kualitas sistem, kualitas informasi, kualitas pelayanan dan kepuasan pengguna berpengaruh positif terhadap net benefit. Penelitian ini dilakukan dengan menganalisis hasil kuesioner yang terkumpul dari 52 responden pengguna sistem WRF BBTMC-BPPT. Metode analisis yang digunakan adalah metode Structural Equation Modeling - Partial Least Square (SEM - PLS) dengan menggunakan software Smart PLS. Hasil analisis menunjukkan bahwa kepuasan pengguna sistem dipengaruhi secara signifikan oleh kualitas informasi dan kualitas sistem. Sedangkan net benefits dipengaruhi secara signifikan oleh kepuasan pengguna dan kualitas pelayanan. Oleh karena itu, perlu adanya perhatian serius dari unit kerja BBTMC-BPPT untuk meningkatkan kualitas informasi dan kualitas sistem WRF agar dapat memberikan pengaruh signifikan terhadap proyek TMC.
\end{abstract}

Kata Kunci: sistem informasi WRF; TMC; SEM-PLS; DeLone-McLean; net benefit

\begin{tabular}{ll}
\hline How to cite: & Arisman, H., \& Budi Hartono (2021) Analisis Kesuksesan Penerapan Sistem Informasi Prediksi Cuaca \\
& Weather Research and Forecasting dalam Mendukung Proyek Teknologi Modifikasi Cuaca. Syntax \\
& Literate: Jurnal Ilmiah Indonesia, 6 (1). \\
E-ISSN: & 2548-1398 \\
Published by: & Ridwan Institute
\end{tabular}




\section{Abstract}

Every project is always supported by adequate facilities and infrastructure to achieve the ultimate goal of the project. The weather modification technology (TMC) project is a unique project that this project aims to increase the intensity of rainfall or accelerate the process of rain in a place. The information system of Weather Research and Forecasting (WRF) is one of the tools used to support the TMC project by providing the required weather data information. Given the importance of the role of the WRF system in this TMC project, it is deemed necessary to conduct an evaluation to determine the success of the implementation of the WRF system. This study evaluates the implementation of the WRF information system measured by the level of satisfaction and net benefits felt by system users in the work unit of the Center for Weather Modification Technology at the Agency for the Assessment and Application of Technology. This study uses the DeLone and McLean Information System Success Model which is modified by eliminating the use construct. This study is used to test whether system quality, information quality, and service quality have a positive effect on system user satisfaction, as well as to test whether system quality, information quality, service quality and user satisfaction has a positive effect on net benefits. This research was conducted by analyzing the results of questionnaires collected from 52 respondents using the WRF BBTMC-BPPT system. The analytical method used is Structural Equation Modeling - Partial Least Square (SEM - PLS) method using Smart PLS software. The results of the analysis show that user satisfaction is significantly influenced by information quality and system quality. Meanwhile, net benefits are significantly influenced by user satisfaction and service quality. Therefore, there needs to be serious attention from the BBTMC work unit to improve the quality of information and the quality of the WRF system so that it can have a significant impact on the TMC project.

Keywords: WRF information system; TMC; SEM-PLS; Delone-McLean; net benefit

Received: 2021-10-20; Accepted: 2021-11-05; Published: 2021-11-20

\section{Pendahuluan}

Teknologi Modifikasi Cuaca (TMC) adalah suatu bentuk intervensi manusia terhadap sistem awan dengan tujuan mengkondisikan cuaca berperilaku sesuai dengan yang dibutuhkan yang umumnya bertujuan untuk meningkatkan intensitas curah hujan ataupun mempercepat proses hujan di suatu tempat (Wirahma et al, 2014). Penerapan TMC di Indonesia telah dilakukan semenjak tahun 1977 atas gagasan dari Presiden Soeharto dan difasilitasi oleh Prof. Dr. Ing BJ Habibie melalui advance teknologi yang menjadi embrio lahirnya Badan Pengkajian dan Penerapan Teknologi (BPPT) pada tahun 1978. TMC telah dilakukan di Indonesia dengan berbagai tujuan yakni diantaranya penambahan curah hujan guna mengatasi kekeringan, pengisian air waduk guna keperluan irigasi dan pembangkit listrik tenaga air (PLTA), pengurangan curah hujan guna mengatasi banjir di suatu daerah, dan pengurangan kabut asap yang disebabkan kebakaran hutan dan lahan. 
Dalam setiap kegiatan penerapan TMC terdapat berbagai macam advance technology yang dapat digunakan untuk membantu kegiatan operasional dilapangan antara lain:

1. Sistem informasi Weather Research and Forecasting (WRF) yang digunakan untuk memprediksi cuaca dari aspek curah hujan, temperature, kelembapan udara, tekanan, angin dan lain sebagainya.

2. Inovasi Artificial Intelligence dalam upaya mitigasi bencana kebakaran hutan dan lahan (karhutla) berupa machine learning untuk memprediksi tinggi muka air lahan gambut yang dapat digunakan sebagai decision support system yang membantu user dalam menentukan kapan waktu yang tepat dilaksanakannya penerapan TMC untuk mitigasi karhutla.

3. Sistem Monitoring Online Kandungan Air Lahan Gambut Indonesia (SMOKIES) sebagai Early Warning System Karhutla kebakaran lahan gambut.

4. Cloud to Ground Lightning for Severe Weather Early Warning System digunakan untuk observasi cuaca khususnya memprediksi adanya petir.

5. Radar Rainfall Observation for Early Warning System (RAINBOWS) guna mendeteksi butir air yang ada di awan dan mendeteksi tipe awan vertikal.

Bagi organisasi terkait dalam penelitian ini adalah Balai Besar Teknologi Modifikasi Cuaca-Badan Pengkajian dan Penerapan Teknologi (BBTMC-BPPT), sistem informasi WRF cukup penting penggunaannya karena berfungsi sebagai alat bantu untuk pencapaian tujuan organisasi melalui penyediaan informasi prediksi cuaca. Sebagai suatu sistem informasi yang telah diimplementasikan dan masih terus digunakan dalam setiap kegiatan TMC, analisis pemanfaatan sistem informasi WRF di lingkungan BBTMC dipandang sangat perlu dilakukan untuk mengetahui faktor-faktor yang mempengaruhi kesuksesan implementasi sistem informasi WRF dalam mendukung pelaksanaan proyek TMC dimana menurut Delone and McLean kesuksesan implementasi suatu SI dapat diukur dari kualitas sistem, kualitas informasi, kualitas layanan, kepuasan pengguna dan net benefit dari SI tersebut. Untuk itu penelitian ini bertujuan untuk mengetahui pengaruh kualitas sistem (System Quality), kualitas pelayanan (Service Quality), kualitas informasi (Information Quality), dan kepuasan pengguna (User Satisfaction) dari sistem informasi model prediksi cuaca WRF terhadap net benefit proyek TMC.

\section{Metode Penelitian}

Penelitian ini menggunakan kuesioner sebagai sarana untuk memperoleh data primer. Kuesioner berisikan demografi responden dan pertanyaan berdasarkan variabel yang diukur. Variabel yang diukur adalah kualitas sistem, kualitas informasi, kualitas layanan, kepuasan pengguna dan manfaat bersih. Tanggapan dari responden bersifat kuantitatif dan diukur dengan menggunakan skala Likert. Kuesioner yang diisi dan dikembalikan oleh responden kemudian diolah lebih lanjut. Data diolah dengan menggunakan Partial Least Square (PLS) yang merupakan bagian dari Structural 
Equation Modeling (SEM). Sedangkan software yang dipergunakan dalam menganalisis data yaitu SmartPLS.

Model penelitian yang digunakan yakni mengadopsi model kesuksesan sistem informasi DeLone dan McLean dengan beberapa modifikasi untuk mengevaluasi keberhasilan implementasi Sistem Informasi sistem informasi WRF dalam mendukung pelaksanaan proyek TMC. Model penelitian ini dapat dilihat pada Gambar 1.

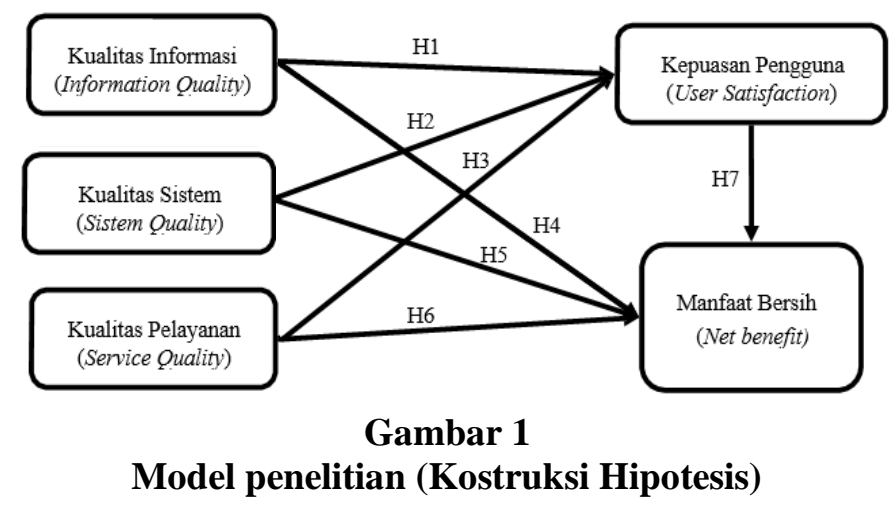

Keterangan:

Model penelitian (Kostruksi Hipotesis)

$\mathrm{H}_{1}$ : Kualitas informasi berpengaruh terhadap kepuasan pengguna.

$\mathrm{H}_{2}$ : Kualitas sistem berpengaruh terhadap kepuasan pengguna (user satisfaction).

$\mathrm{H}_{3}$ : Kualitas pelayanan berpengaruh terhadap kepuasan pengguna.

$\mathrm{H}_{4}$ : Kualitas informasi berpengaruh terhadap net benefit

$\mathrm{H}_{5}$ : Kualitas sistem berpengaruh terhadap net benefit.

$\mathrm{H}_{6}$ : Kualitas pelayanan berpengaruh terhadap net benefit.

$\mathrm{H}_{7}$ : Kepuasan pengguna (User Satisfaction) berpengaruh terhadap net benefit.

Untuk mencegah timbulnya berbagai tafsiran terhadap variabel-variabel yang digunakan maka harus didefinisikan terlebih dahulu variabel-variabel tersebut. Secara umum variabel-variabel yang digunakan dalam penelitian ini adalah sebagai berikut:

1. Kualitas Informasi (X1)

Mengukur kualitas output dari sistem informasi itu sendiri menyangkut nilai, manfaat, relevansi dan urgensi dari informasi yang dihasilkan (DeLone \& McLean, 1992).

2. Kualitas Sistem (X2)

Digunakan untuk mengukur kualitas sistem teknologi informasi itu sendiri. Kualitas sistem yakni kombinasi kualitas dari perangkat keras (hardware) dan perangkat lunak (software) yang digunakan dalam sistem informasi tersebut. Fokusnya terletak pada performa dari sistem, yang menunjukkan seberapa baik kemampuan hardware, software, kebijakan, mekanisme dan sistem informasi dapat memberikan informasi sesuai kebutuhan pengguna (DeLone \& McLean, 1992).

3. Kualitas Layanan (X3)

Merupakan seluruh dukungan yang diberikan oleh penyedia layanan kepada pengguna sistem (DeLone \& McLean, 2003). 


\section{Kepuasan Pengguna (Y1)}

Merupakan respon pemakai terhadap penggunaan keluaran sistem informasi (DeLone $\&$ McLean, 1992).

\section{Net Benefit (Y2)}

Hasil bersih atau keutungan yang dirasakan oleh organisasi atau perusahaan setelah menerapkan sistem informasi tersebut (DeLone \& McLean, 2003).

Adapun tahapan penelitian yang dilakukan guna penelitian ini agar berjalan dengan baik dan tetap fokus pada tujuan penelitian adalah sebagai berikut:

1. Observasi Lingkungan Kerja

Penelitian dimulai dengan pengumpulan data terkait lingkungan kerja BBTMC-BPPT dengan melakukan studi literatur melalui jurnal-jurnal yang dierbitkan oleh BBTMCBPPT dan juga wawancara dengan beberapa pegawai BBTMC-BPPT terkait pelaksanaan teknologi modifikasi cuaca.

2. Perumusan Masalah

Menentukan pertanyaan-pertanyaan mengenai masalah yang akan dibahas dalam penelitian dan menentukan ruang lingkup pembahasannya.

3. Identifikasi Variabel

Mengidentifikasi variabel-variabel yang berpotensi mempengaruhi kesuksesan penerapan sistem informasi prediksi cuaca weather research and forecasting dalam mendukung pelaksanaan proyek TMC.

4. Membuat Model Penelitian

Pembuatan model penelitian yang didasarkan pada studi literatur dan menentukan variabel independen dan dependen yang disesuaikan dengan kebutuhan dalam penelitian ini.

5. Merancang Instrumen Penelitian

Instrumen penelitian dirancang sesuai dengan kebutuhan dalam penelitian ini.

6. Pengambilan Data

Data diperoleh dengan melakukan survei menggunakan kuisioner untuk mendapatkan penilaian dari user terhadap sistem informasi prediksi cuaca weather research and forecasting.

7. Pengolahan dan Analsis Data

Pengolahan data menggunakan alat bantu penelitian berupa software Smart PLS guna melakukan pengujian structural equation model-partial least square (SEM-PLS) untuk mencari pengaruh antar variabel.

8. Penarikan Kesimpulan

Menarik kesimpulan dengan menjawab pertanyaan-pertanyaan pada rumusan masalah yang berdasarkan hasil pengolahan dan analisis data serta dijadikan dasar pemberian saran kepada unit kerja BBTMC-BPPT guna pengembangan sistem informasi prediksi cuaca weather research and forecasting yang lebih baik.

Populasi dari penelitian ini adalah keseluruhan pegawai BBTMC-BPPT dan metode sampling yang digunakan adalah purposive sampling dimana responden dalam penelitian ini telah ditentukan yakni pegawai BBTMC yang pernah menggunakan sistem 
informasi WRF dalam pelaksanaan TMC baik pegawai dibidang penerapan teknologi, pelayanan teknologi maupun pada bagian umum.

Menurut (Hair et al., 2017) ukuran sampel yang digunakan dalam penelitian dengan metode SEM-PLS harus didasari oleh aturan jumlah minimal sampel harus sama dengan atau lebih besar dari:

1. 10 kali jumlah indikator formatif terbanyak yang digunakan untuk mengukur suatu konstruk, atau

2. 10 kali jumlah jalur struktural terbanyak yang ditujukan pada konstruksi tertentu pada model structural

Berdasarkan teori tersebut, jumlah sampel secara keseluruhan yang semestinya digunakan dalam penelitian ini adalah sebanyak 50 sampel atau responden. Hal ini dikarenakan jumlah indikator formatif terbesar yang digunakan dalam penelitian ini adalah sebanyak 5 indikator.

\section{Hasil dan Pembahasan}

Berdasarkan hasil survei, penelitian ini mendapat 52 tanggapan responden yang kemudian diolah menggunakan metode structural equation model-partial least square (SEM-PLS) dengan bantuan software SmartPLS. Pengolahan data dibagi menjadi 2 bagian yakni evaluasi model pengukuran (Outer Model) dan evaluasi model struktural (Inner Model).

\section{A. Analisis Model Pengukuran (Outer Model)}

Analisis model pengukuran (Outer Model) dilakukan guna memberikan gambaran hubungan antara indikator dengan variabel laten atau konstruknya. Pengukuran yang digunakan untuk menilai outer model yakni pengujian validitas konvergen, validitas diskriminan, dan reliabitas.

\section{Uji Validitas Konvergen}

Uji validitas konvergen dari model pengukuran dengan model reflektif indikator dinilai berdasarkan standardized factor loading yang menunjukkan nilai besarnya korelasi dari setiap indikator dengan variabel latennya. Nilai factor loading yang melebihi 0,70 dinyatakan sebagai suatu nilai atau ukuran yang ideal atau valid sebagai indikator yang mengukur variabel latennya (Hair, Risher, Sarstedt, \& Ringle, 2019). Semakin tinggi nilai factor loading semakin penting peranan loading dalam menginterprestasi matrik faktor.

Adapun hasil pengujian validitas konvergen dalam penelitian ini dapat dilihat pada Tabel 1 .

Tabel 1

Nilai factor loading

\begin{tabular}{clc}
\hline Variabel Laten & \multicolumn{1}{c}{$\begin{array}{c}\text { Variabel } \\
\text { Manifest/Indikator }\end{array}$} & Factor Loading \\
\hline Kualitas Informasi (X1) & 1. Kelengkapan (X1.1) & 0.802 \\
\cline { 2 - 3 } & 2. Keandalan (X1.2) & 0.862 \\
\cline { 2 - 3 } & 3. Kesesuaian (X1.3) & 0.86 \\
\cline { 2 - 3 } & 4. Ketepatan (X1.4) & 0.784 \\
\hline
\end{tabular}


Analisis Kesuksesan Penerapan Sistem Informasi Prediksi Cuaca Weather Research and Forecasting dalam Mendukung Proyek Teknologi Modifikasi Cuaca

\begin{tabular}{|c|c|c|}
\hline \multirow[t]{5}{*}{ Kualitas Sistem (X2) } & 1. Waktu Respon (X2.2) & 0.728 \\
\hline & 2. Ketepat Waktuan (X2.2) & 0.744 \\
\hline & 3. Kemudahan Akses (X2.3) & 0.849 \\
\hline & $\begin{array}{l}\text { 4. Tampilan Antar Muka } \\
(\mathrm{X} 2.4)\end{array}$ & 0.823 \\
\hline & $\begin{array}{l}\text { 5. Kemudahan Mempelajari } \\
(\mathrm{X} 2.5)\end{array}$ & 0.728 \\
\hline \multirow[t]{3}{*}{ Kualitas Layanan (X3) } & $\begin{array}{l}\text { 1. Kecepatan Penanganan } \\
\text { Masalah (X3.1) }\end{array}$ & 0.836 \\
\hline & $\begin{array}{l}\text { 2. Kepedulian } \\
\text { Pengembangan (X3.2) }\end{array}$ & 0.893 \\
\hline & 3.Perhatian Individu (X3.3) & 0.755 \\
\hline \multirow[t]{4}{*}{$\begin{array}{l}\text { Kepuasan } \\
\text { (Y1) }\end{array}$} & $\begin{array}{l}\text { 1. Memenuhi Harapan } \\
\text { (Y1.1) }\end{array}$ & 0.773 \\
\hline & 2. Kinerja (Y1.2) & 0.887 \\
\hline & 3. Efektif dan Efisien (Y1.3) & 0.925 \\
\hline & $\begin{array}{l}\text { 4. Menambah Pengetahuan } \\
\text { (Y1.4) }\end{array}$ & 0.826 \\
\hline \multirow[t]{2}{*}{ Net Benefit (Y2) } & 1. Produktivitas (Y2.1) & 0.883 \\
\hline & 2. Profitabilitas (Y2.2) & 0.91 \\
\hline
\end{tabular}

Berdasarkan hasil tersebut maka dapat disimpulkan bahwa factor loading telah memenuhi standar nilai validitas konvergen atau dapat disebutkan bahwa indikator-indikator yang digunakan tersebut valid secara konvergen untuk membentuk dimensi konstruknya.

2. Uji Validitas Diskriminan

Uji validitas diskriminan bertujuan untuk menguji apakah indikatorindikator yang digunakan untuk merefleksikan suatu konstruk tidak berkorelasi tinggi dengan indikator-indikator dari konstruk yang lain. Validitas diskriminan dari suatu model pengukuran reflektif dinilai berdasarkan cross loading pengukuran antar konstruk. Jika hasil korelasi konstruk dengan item pengukuran konstruk itu sendiri lebih besar daripada dengan item pengukuran konstruk lainnya, maka menunjukkan bahwa konstruk tersebut memprediksi ukuran pada dimensi indikatornya lebih baik daripada ukuran dengan dimensi indikator pada konstruk lainnya. Metode untuk mencari validitas diskriminan adalah dengan membandingkan nilai akar kuadrat pada Average Variance Extracted (AVE) setiap konstruk dengan nilai korelasi antara konstruk dengan konstruk lainnya (latent variable correlation). Nilai kuadrat AVE penelitian ini ditunjukkan pada Tabel 2.

Tabel 2

Nilai Kuadrat AVE

\begin{tabular}{lccccc}
\hline Variabel & $\begin{array}{c}\text { Kepuasan } \\
\text { Pengguna }\end{array}$ & $\begin{array}{c}\text { Kualitas } \\
\text { Informasi }\end{array}$ & $\begin{array}{c}\text { Kualitas } \\
\text { Layanan }\end{array}$ & $\begin{array}{c}\text { Kualitas } \\
\text { Sistem }\end{array}$ & $\begin{array}{c}\text { Net } \\
\text { Benefit }\end{array}$ \\
\hline $\begin{array}{l}\text { Kepuasan } \\
\text { Pengguna }\end{array}$ & 0.854 & & & & \\
\hline $\begin{array}{l}\text { Kualitas } \\
\text { Informasi }\end{array}$ & 0.64 & 0.828 & & & \\
\hline
\end{tabular}




\begin{tabular}{lccccc}
\hline $\begin{array}{l}\text { Kualitas } \\
\text { Layanan }\end{array}$ & 0.571 & 0.525 & 0.83 & & \\
\hline $\begin{array}{l}\text { Kualitas } \\
\text { Sistem }\end{array}$ & 0.681 & 0.636 & 0.653 & 0.776 & \\
\hline $\begin{array}{l}\text { Net } \\
\text { Benefit }\end{array}$ & 0.602 & 0.594 & 0.618 & 0.542 & 0.897 \\
\hline
\end{tabular}

Berdasarkan Tabel 2 dapat dijelaskan bahwa nilai kuadrat AVE (nilai yang bersusun diagonal) pada masing-masing konstruk memiliki nilai lebih tinggi dibandingkan dengan nilainya dengan konstruk yang lain sehingga dapat disimpulkan model memiliki validitas diskriminan yang baik.

3. Uji Reliabilitas

Uji Reliabilitas dalam penelitian ini menggunakan dua metode yakni Cronbach's alpha dan composite reliability dimana berdasarkan rule of thumb, nilai dari cronbach's alpha dan composite reliability harus lebih besar dari 0,7 (Hair et al., 2019). Nilai cronbach's alpha dan composite reliability dapat dilihat pada Tabel 3 .

Tabel 3

Hasil Uji Reability

\begin{tabular}{ccc}
\hline Variabel & Cronbach's Alpha & $\begin{array}{c}\text { Composite } \\
\text { Reliability }\end{array}$ \\
\hline Kepuasan Pengguna & 0.876 & 0.915 \\
\hline Kualitas Informasi & 0.846 & 0.897 \\
\hline Kualitas Layanan & 0.772 & 0.869 \\
\hline Kualitas Sistem & 0.834 & 0.883 \\
\hline Net Benefit & 0.757 & 0.891 \\
\hline
\end{tabular}

Berdasarkan Tabel 3 terlihat bahwa seluruh variabel laten yang digunakan dalam penelitian ini mendapat nilai lebih besar dari 0,7 sehingga dapat disimpulkan model variabel laten yang digunakan dianggap reliabel, sehingga hasil analisis yang tersaji berdasarkan hasil uji validitas dan reabilitas dapat dilanjutkan untuk pengukuran model struktural (inner model).

B. Analisis Model Struktural (Inner Model)

Analisis model struktural (inner model) bertujuan untuk mengetahui hubungan antara variabel laten yang satu dengan variabel laten yang lainnya yang telah dihipotesiskan dalam model penelitian. Analisis pada model struktural dilakukan dengan melihat nilai kolinearitas (VIF), koefisien determinasi $\left(\mathrm{R}^{2}\right)$ dan relevansi prediktif $\left(\mathrm{Q}^{2}\right)$.

1. Nilai Kolinearitas (VIF)

Nilai kolinearitas atau Variance Inflation Factor (VIF) digunakan untuk mengevaluasi multikolinearitas. Nilai VIF yang ideal adalah kurang dari 3 (Hair et al., 2019). Nilai VIF lebih dari 3 menunjukkan adanya multikolinearitas yang dapat menyebabkan bias dalam persamaan regresi. Nilai VIF inner model ditunjukkan pada Tabel 4. 
Tabel 4

Nilai VIF pada Inner Model

\begin{tabular}{lcc}
\hline \multicolumn{1}{c}{ Variabel } & Kepuasan Pengguna & Net Benefit \\
\hline Kepuasan Pengguna & & 2.222 \\
\hline Kualitas Informasi & 1.739 & 1.963 \\
\hline Kualitas Layanan & 1.807 & 1.863 \\
\hline Kualitas Sistem & 2.197 & 2.511 \\
\hline
\end{tabular}

Berdasarkan Tabel 4 menunjukkan bahwa tidak adanya multikolinearitas yang dapat menyebabkan bias dalam inner model yang digunakan.

2. Koefisien Determinasi $\left(\mathrm{R}^{2}\right)$

Nilai $\mathrm{R}^{2}$ menunjukkan varians yang dapat dijelaskan dalam suatu konstruk/variabel dependen karena pengaruh prediktornya. Tabel 5 menunjukkan nilai $\mathrm{R}^{2}$.

Tabel 5

Nilai $\mathbf{R}^{2}$

\begin{tabular}{cc}
\hline Variabel Dependen & $\mathbf{R}^{\mathbf{2}}$ \\
\hline Kepuasan Pengguna & 0.55 \\
\hline Net Benefit & 0.512 \\
\hline
\end{tabular}

Tabel 5 menunjukkan nilai $\mathrm{R}^{2}$ pada variabel dependen kepuasan pengguna (Y1) diperoleh nilai sebesar 0,55 dimana hasil ini menunjukkan bahwa variabelvariabel prediktornya yakni variabel independen kualitas informasi, kualitas sistem dan kualitas layanan dapat menjelaskan variabel dependen Kepuasan Pengguna sebesar 55\% sedangkan sisanya $45 \%$ dijelaskan oleh faktor atau variabel lain di luar model penelitian ini. Di samping itu, nilai $\mathrm{R}^{2}$ pada variabel dependen net benefit (Y2) diperoleh nilai yakni 0,512 dimana hasil ini menunjukkan bahwa variabel-variabel prediktornya yakni variabel kualitas sistem, kualitas informasi, kualitas pelayanan, dan kepuasan pengguna dapat menjelaskan variabel net benefit sebesar 51,2\% sedangkan sisanya $48,8 \%$ dijelaskan oleh faktor atau variabel lainnya di luar model penelitian ini.

3. Relevansi Prediktif $\left(Q^{2}\right)$

Pengujian relevansi prediktif $\left(\mathrm{Q}^{2}\right)$ bertujuan guna menentukan seberapa baik nilai relevansi prediksi antara variabel laten endogen terhadap variabel laten eksogennya (variabel prediktornya). Model dapat dikatakan mempunyai relevansi prediktif bila nilai $\mathrm{Q}^{2}$ yang diperoleh lebih dari 0 , sedangkan nilai $\mathrm{Q}^{2}$ kurang dari 0 menunjukkan bahwa model kurang memiliki relevansi prediktif (Hair et al., 2019). Nilai relevansi prediktif $\left(Q^{2}\right)$ ditunjukkan pada Tabel 6. 


\begin{tabular}{cc}
\multicolumn{2}{c}{$\begin{array}{c}\text { Tabel 6 } \\
\text { Nilai Q }\end{array}$} \\
\hline Variabel Dependen & Q Square \\
\hline Kepuasan Pengguna & 0.351 \\
\hline Net Benefit & 0.328 \\
\hline
\end{tabular}

Berdasarkan Tabel 6 menunjukkan bahwa model penelitian yang digunakan yakni semua variabel dependen mempunyai nilai $Q^{2}$ yang lebih besar dari 0 sehingga pengukuran prediksi variabel yang dilakukan oleh model telah dianggap relevan.

C. Pengujian Hipotesis

Hipotesis yang dirumuskan dalam model penelitian ini diinterpretasikan berpengaruh signifikan (menolak $\mathrm{H}_{0}$ ) apabila $\mathrm{t}$ hitung $\geq 1,982$ dan juga $\mathrm{P}$ Value $\leq$ 0,05 . Sebaliknya hipotesis diinterpretasikan berpengaruh tidak signifikan (gagal menolak $\mathrm{H}_{0}$ ) jika t hitung $\leq 1,982$ dan $\mathrm{P}$ Value $\geq 0,05$. Tabel 7 menunjukkan hasil path coefficient dan nilai signifikansi setelah dilakukan proses bootstrapping.

Tabel 7

Path Coefficient dan Nilai Signifikansi

\begin{tabular}{|c|c|c|c|c|c|c|c|c|}
\hline \multirow[t]{2}{*}{ HIPOTESIS } & \multicolumn{2}{|c|}{ Path/Jalur } & \multirow{2}{*}{$\begin{array}{c}\text { Original } \\
\text { Sample } \\
\text { (O) }\end{array}$} & \multirow{2}{*}{$\begin{array}{c}\text { Sample } \\
\text { Mean } \\
\text { (M) }\end{array}$} & \multirow{2}{*}{$\begin{array}{l}\text { Standar } \\
\text { Deviation } \\
\text { (STDEV) }\end{array}$} & \multirow{2}{*}{$\begin{array}{c}\mathrm{T} \\
\text { Statistics/O/STDEV| }\end{array}$} & \multirow{2}{*}{$\begin{array}{c}\text { P } \\
\text { Values }\end{array}$} & \multirow[t]{2}{*}{ Interpretasi } \\
\hline & Dari & $\mathrm{Ke}$ & & & & & & \\
\hline H1 & $\begin{array}{c}\text { Kualitas } \\
\text { Informasi } \\
\text { (X1) }\end{array}$ & $\begin{array}{c}\text { Kepuasan } \\
\text { Pengguna } \\
\text { (Y1) }\end{array}$ & 0,318 & 0,316 & 0,144 & 2,207 & 0.028 & Signifikan \\
\hline $\mathrm{H} 2$ & $\begin{array}{c}\text { Kualitas } \\
\text { Sistem } \\
(\mathrm{X} 2)\end{array}$ & $\begin{array}{c}\text { Kepuasan } \\
\text { Pengguna } \\
\text { (Y1) }\end{array}$ & 0,376 & 0,375 & 0,163 & 2,309 & 0.021 & Signifikan \\
\hline H3 & $\begin{array}{c}\text { Kualitas } \\
\text { Pelayanan } \\
\text { (X3) }\end{array}$ & $\begin{array}{c}\text { Kepuasan } \\
\text { Pengguna } \\
\text { (Y1) }\end{array}$ & 0,159 & 0,175 & 0,133 & 1.192 & 0.234 & $\begin{array}{c}\text { Tidak } \\
\text { Signifikan }\end{array}$ \\
\hline $\mathrm{H} 4$ & $\begin{array}{l}\text { Kualitas } \\
\text { Informasi } \\
\text { (X1) }\end{array}$ & $\begin{array}{c}\text { Net } \\
\text { Benefit } \\
\text { (Y2) }\end{array}$ & 0,268 & 0,262 & 0,171 & 1.572 & 0.117 & $\begin{array}{c}\text { Tidak } \\
\text { Signifikan }\end{array}$ \\
\hline H5 & $\begin{array}{c}\text { Kualitas } \\
\text { Sistem } \\
(\mathrm{X} 2)\end{array}$ & $\begin{array}{c}\text { Net } \\
\text { Benefit } \\
\text { (Y2) }\end{array}$ & 0,355 & 0,346 & 0,158 & 2,253 & 0.025 & Signifikan \\
\hline H6 & $\begin{array}{l}\text { Kualitas } \\
\text { Pelayanan } \\
\text { (X3) }\end{array}$ & $\begin{array}{c}\text { Net } \\
\text { Benefit } \\
\text { (Y2) }\end{array}$ & 0,355 & 0,346 & 0,158 & 2.253 & 0.025 & Signifikan \\
\hline H7 & $\begin{array}{c}\text { Kepuasan } \\
\text { Pengguna } \\
\text { (Y1) }\end{array}$ & $\begin{array}{c}\text { Net } \\
\text { Benefit } \\
\text { (Y2) }\end{array}$ & 0,247 & 0,263 & 0,186 & 2,431 & 0.028 & Signifikan \\
\hline
\end{tabular}

Hasil pengujian hipotesis dalam penelitian ini adalah sebagai berikut:

Hipotesis 1: Kualitas informasi berpengaruh signifikan terhadap kepuasan pengguna. Keputusan: Menolak $\mathrm{H}_{0}$, terdapat cukup bukti bahwa kualitas informasi memberikan pengaruh yang signifikan terhadap kepuasan pengguna. Semakin baik kualitas informasi dari sistem WRF maka akan semakin meningkatkan kepuasan pengguna sistem WRF. Sebaliknya semakin rendah kualitas informasi dari WRF maka akan menurunkan kepuasan pengguna. Kualitas informasi adalah kualitas keluaran (output) yang berupa informasi atau data yang dihasilkan oleh sistem WRF. Korelasi positif diantara kedua konstruk tersebut menggambarkan keterikatan antara 
kualitas informasi yang dihasilkan dengan tingkat kepuasan yang diperoleh pengguna sistem informasi.

Hipotesis 2: Kualitas sistem berpengaruh signifikan terhadap kepuasan pengguna (user satisfaction) Keputusan: Menolak $\mathrm{H}_{0}$, terdapat cukup bukti bahwa kualitas sistem berpengaruh signifikan terhadap kepuasan pengguna (user satisfaction) sistem informasi WRF. Semakin baik atau tinggi kualitas sistem dari WRF maka akan semakin meningkatkan kepuasan pengguna WRF. Sebaliknya bila semakin rendah kualitas sistem dari WRF maka akan menurunkan kepuasan pengguna sistem WRF. Kecepatan waktu respon, ketepat waktuan, kemudahan akses, tampilan antarmuka (user interface) dan kemudahan mempelajari sistem WRF telah memberikan pengaruh signifikan terhadap kepuasan pengguna. Pengguna WRF merasa terbantu dalam menyelesaikan tugas dengan menggunakan sistem WRF. Hasil penelitian ini sesuai dengan model kesuksesan sistem informasi dari (DeLone \& McLean, 2003) yang menjelaskan bahwa salah satu faktor yang mempengaruhi efektifitas suatu sistem informasi adalah kualitas sistem. Kualitas sistem yang baik akan mempengaruhi kepuasan pengguna. Hasil penelitian ini sejalan dengan penelitian (Hanmer, 2004), (Livari, 2005), (Roldán \& Leal, 2003), (Rai, Lang, \& Welker, 2002) yang menyatakan bahwa terdapat hubungan yang signifikan antara kualitas sistem dan kepuasan pengguna.

Hipotesis 3: Kualitas pelayanan berpengaruh signifikan terhadap kepuasan pengguna. Keputusan: Gagal menolak $\mathrm{H}_{0}$, tidak terdapat cukup bukti bahwa kualitas pelayanan telah memberikan pengaruh signifikan terhadap kepuasan pengguna. Responden merasa masih kurangnya perhatian dari pengembang sistem guna mengajarkan pegawai baru ataupun pegawai lama untuk memahami WRF, kurangnya fokus terhadap pengembangan sistem WRF secara berkala, serta masih kurangnya respon dari pengembang sistem terhadap keluhan ataupun masukkan dari pengguna sistem WRF.

Hipotesis 4: Kualitas informasi berpengaruh signifikan terhadap net benefit. Keputusan: Gagal menolak $\mathrm{H}_{0}$, tidak terdapat cukup bukti bahwa kualitas informasi berpengaruh signifikan terhadap net benefit. Semakin tingginya kualitas informasi yang ada pada WRF akan meningkatkan net benefit dari proyek TMC. Kelengkapan data yang tersedia pada sistem, keakuratan informasi, format yang mudah dipahami, informasi yang selalu diperbaharui dan informasi yang relevan masih dirasakan kurang dalam mendukung pelaksanaan proyek TMC. Hasil pengujian secara tidak langsung menunjukkan bahwa kualitas informasi memberikan pengaruh signifikan terhadap net benefit melalui kepuasan pengguna sehingga peningkatan kualitas informasi akan meningkatkan net benefit apabila kepuasan pengguna meningkat.

Hipotesis 5: Kualitas sistem berpengaruh signifikan terhadap net benefit. Keputusan: Gagal menolak $\mathrm{H}_{0}$, tidak terdapat cukup bukti bahwa kualitas sistem memberikan pengaruh signifikan terhadap net benefit. Net benefit adalah manfaat yang didapatkan baik oleh pengguna maupun oleh instansi terkait dalam hal ini instansi BBTMC-BPPT. Kualitas sistem yang tercermin dalam indikator 
pengukurnya tidak secara langsung mempengaruhi produktifitas dan profitabilitas proyek TMC dimana hasil pengujian secara tidak langsung menunjukkan bahwa kualitas sistem memberikan pengaruh positif terhadap net benefit melalui kepuasan pengguna. Hal ini menyatakan bahwa dengan meningkatkan kualitas sistem dari WRF maka dapat meningkatkan kepuasan penggunanya sehingga akan memberikan dampak signifikan pada net benefit proyek TMC. Hasil penelitian ini sejalan dengan model kesuksesan sistem informasi (DeLone \& McLean, 2003) yang menyatakan bahwa kualitas sistem memberikan pengaruh terhadap net benefit melalui kepuasan pengguna.

Hipotesis 6: Kualitas pelayanan berpengaruh signifikan terhadap net benefit Keputusan: Menolak $\mathrm{H}_{0}$, terdapat cukup bukti bahwa kualitas pelayanan memberikan pengaruh signifikan terhadap net benefit. Pelayanan yang diberikan oleh tim pengembang sistem WRF telah memberikan kontribusi dalam hal pengembangan dan penerapan teknologi guna mendukung suksesnya proyek TMC.

Hipotesis 7: Kepuasan pengguna (User Satisfaction) berpengaruh signifikan terhadap net benefit. Keputusan: Menolak $\mathrm{H}_{0}$, terdapat cukup bukti bahwa Kepuasan pengguna (User Satisfaction) berpengaruh signifikan terhadap net benefit. Semakin tinggi kepuasan pengguna WRF akan semakin meningkatkan net benefit instansi BBTMC -BPPT. Kualitas sistem dan kualitas informasi menyeluruh dapat meningkatkan job performance pengguna WRF. Hasil penelitian ini mendukung model kesuksesan sistem informasi (DeLone \& McLean, 2003) yang telah membuktikan bahwa kepuasan pengguna berpengaruh terhadap keuntungan/manfaat sistem bagi organisasi. Ketika para pengguna puas terhadap sistem informasi dan mengintegrasikan sistem informasi ke rutinitas mereka, maka sistem informasi menjadi efektif dan berpengaruh terhadap kinerja organisasi.

Prioritas kebijakan yang perlu dilakukan guna peningkatan net benefit proyek TMC terkait penerapan sistem informasi WRF yakni:

1. Peningkatan kepuasan pengguna terutama terkait kualitas informasi dan kualitas sistem WRF.

2. Indikator yang menjadi prioritas perhatian pada konstruk kualitas informasi adalah keandalan karena memiliki korelasi paling tinggi, dimana informasi prediksi cuaca yang dihasilkan oleh sistem informasi WRF harus selalu dapat diandalkan dan dipercaya oleh user.

3. Indikator kemudahan akses menjadi prioritas perhatian pada kualitas sistem WRF dimana sistem informasi WRF harus dapat dengan mudah diakses oleh user dimanapun dan kapanpun bila diperlukan. 


\section{Kesimpulan}

Berdasarkan penelitian yang telah dilakukan, maka dapat diambil kesimpulan sebagai berikut: 1) Kualitas informasi (Information Quality) dan kualitas sistem (System Quality) dari sistem informasi model prediksi cuaca WRF berpengaruh signifikan terhadap kepuasan penggunanya (User Satisfaction), sedangkan kualitas pelayanan (Service Quality) dari sistem informasi model prediksi cuaca WRF tidak berpengaruh signifikan terhadap kepuasan penggunanya (User Satisfaction). 2) Kualitas informasi (Information Quality) dan kualitas sistem (System Quality) dari sistem informasi prediksi cuaca WRF tidak berpengaruh signifikan terhadap net benefit proyek TMC, sedangkan kualitas pelayanan (Service Quality), dan kepuasan pengguna (User Satisfaction) dari sistem informasi prediksi cuaca WRF berpengaruh signifikan terhadap net benefit proyek TMC. 


\section{BIBLIOGRAFI}

DeLone, William H., \& McLean, Ephraim R. (1992). Information systems success: The quest for the dependent variable. Information Systems Research, 3(1), 60-95. Google Scholar

DeLone, William H., \& McLean, Ephraim R. (2003). The DeLone and McLean model of information systems success: a ten-year update. Journal of Management Information Systems, 19(4), 9-30. Google Scholar

Hair, Joseph F., Hult, G. Tomas M., Ringle, Christian M., Sarstedt, Marko, Richter, Nicole F., \& Hauff, Sven. (2017). Partial Least Squares Strukturgleichungsmodellierung: Eine anwendungsorientierte Einführung. Vahlen. Google Scholar

Hair, Joseph F., Risher, Jeffrey J., Sarstedt, Marko, \& Ringle, Christian M. (2019). When to use and how to report the results of PLS-SEM. European Business Review. Google Scholar

Hanmer, Lyn. (2004). Assessment of Success of a Computerised Hospital Information System in a Public Sector Hospital in South Africa. MEDINFO. IOS Press. Februari, 12. Google Scholar

Livari, Juhani. (2005). An Empirical Test of The DeLone-McLean Model of Information System Success, Dataabase for Advance in Information System (DFA). ISSN: 1532-0936. Volume 36. ProQuest Company. Google Scholar

Rai, Arun, Lang, Sandra S., \& Welker, Robert B. (2002). Assessing the validity of IS success models: An empirical test and theoretical analysis. Information Systems Research, 13(1), 50-69. Google Scholar

Roldán, José L., \& Leal, Antonio. (2003). A Validation Test of an Adaptation of the DeLone and McLean's Model in the Spanish EIS Field. In Critical reflections on information systems: A systemic approach (pp. 66-84). IGI Global. Google Scholar

Wirahma, Samba, Seto, Tri Handoko, \& Athoillah, Ibnu. (2014). Pemanfaatan Teknologi Modifikasi Cuaca Untuk Perkebunan Kelapa Sawit. Jurnal Sains \& Teknologi Modifikasi Cuaca, 15(1), 39. https://doi.org/10.29122/jstmc.v15i1.2656. Google Scholar

\section{Copyright holder:}

Hendra Arisman, Budi Hartono (2021)

First publication right:

Syntax Literate: Jurnal Ilmiah Indonesia

This article is licensed under:

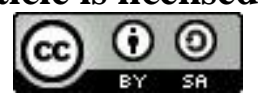

